\title{
Capacity Development Processes within a Social Movement: Päkehä Treaty Workers' Movement
}

\author{
Jen Margaret
}

\begin{abstract}
This article considers capacity development processes within the movement of non-indigenous people who support indigenous sovereignty in Aotearoa/New Zealand. Based on action research by a movement member, it explores if and how learning contributes to the overall capacity development of the movement. The research focused on learning with regard to the relationship-based practice of working with Mäori activists. It highlights the unintentional, informal and embedded nature of this learning. While individuals were engaged in ongoing learning, there was limited sharing of learning within the movement. In exploring the reasons for this, the complexity of facilitating capacity development with regard to relationship-based practice becomes evident. Capacity development through learning within this social movement was largely unintentional. Two intentional processes are identified as being important means of facilitating capacity development within a social movement: the informal process of intergenerational questioning and the structured process of action research.
\end{abstract}

\section{Introduction \\ This article considers capacity development processes within the Päkehä (New Zealanders of European descent) Treaty workers' movement through an analysis of learning processes. It is based on action research undertaken by myself, as a third generation member of the movement. ${ }^{1}$ The research highlights the unintentional, informal and embedded nature of the learning. Intergenerational questioning and action research emerge as examples of intentional processes to facilitate capacity development. After introducing the Päkehä Treaty workers' movement and providing background to my research, these unintended and intended capacity development processes and their inherent complexities will be explored.}

\section{The Päkehä Treaty workers' movement}

The Treaty of Waitangi was a voluntary agreement between hap $\ddot{u}^{2}$ and the British Crown in 1840. It allowed the British the right to govern their own people in New Zealand, and it affirmed Mäori ${ }^{3}$ sovereignty. Subsequent to the signing, the colonial government's consistent violations of the Treaty have had major detrimental impacts on the Mäori people. Mäori have consistently protested about how the Treaty has been violated and small numbers of Päkehä have supported them.

The Päkehä Treaty workers' movement emerged in the early 1980s in response to calls from Mäori for Päkehä to learn about their responsibilities under the Treaty - Päkehä were challenged to educate their own people about it. From this time, a Päkehä movement developed alongside and in relationship to the Mäori Tino

Rangatiratanga (self-determination) movement.

The Päkehä Treaty workers' movement focuses on shifting Päkehä society towards social justice for Mäori and aims to neutralise resistance to Mäori efforts for self-determination. Members share a broad political vision of Tino Rangatiratanga and undertake a range of practices to achieve this, a key focus being adult education about the Treaty and the impact of colonisation on Mäori. Central to the Päkehä approach to social justice is a focus on change within our own, dominant culture. 
I am Päkehä, raised in a farming community where my ancestors settled as migrants from the UK in the 1850s. I first learned about the Treaty of Waitangi in a university postgraduate course in the mid-1990s and was outraged that I had never been taught about this critical piece of New Zealand history during my many years in formal education. This motivated me as an adult educator to begin facilitating Treaty education workshops. Since 2000 I have been active in local and national Treaty action networks.

\section{Background to the research \\ 3.1 Research focus}

This article draws on academic research I undertook in 2008-9, which explored the following questions: 'What influences learning for members of the Päkehä Treaty workers' movement? What impacts on the sharing of learning between movement members? What are the implications of this study for future practice and research in this and other social justice movements?' (Margaret 2009).

We, in the third generation of the Päkehä Treaty movement, have benefited from the guidance that elders have provided. They paved the way in terms of building relationships with Mäori and introduced us to the Mäori of our own generation with whom we now work. In this work, we have been aware that our reputation has derived in part from the elders we are associated with and that in turn, our actions reflect back on them. Because of this we have seen it as important to respect the knowledge and wisdom of our elders. Reflecting on this, I realised that in my own practice I tended to assume that respecting their wisdom meant I should use the same approaches as they have done to this work.

As a founder of a group of my own generation of Treaty workers, tensions arose when people within the group took different approaches to the work that were perceived as having the potential to undermine relationships with Mäori activists. This made me question whether we had explicitly discussed our approach and the rationale for it within the group. It made me wonder whether doing so might have been beneficial to the relationships within the movement and the efficacy of our work. It raised questions of: Do we consciously pass on knowledge to newcomers in the movement? If so, how do we do this? If not, why not? How have we learned and how do we expect others to learn? How do we learn/respect the work of those who have gone before but allow our own processes to emerge?

Alongside these movement experiences, I was a participant in an Institute of Development Studies (IDS) initiative, 'Facilitating Learning in Action for Social Change' (FLASC), which aimed to improve the efficacy of progressive social change work through exploring facilitation of learning processes in social change contexts. This involved undertaking a personal inquiry and articulating how my theory of social change informs my practice. I focused my inquiry on learning in the Päkehä Treaty workers' movement, which made me realise how much I was using the approach we had inherited from the elders. This led me to want to understand the approach better and to engage in a process that would encourage others in the movement to consider how learning was happening and what implications this might have for our practice. I constructed my research as a way of addressing these questions and as an attempt to facilitate a capacity development process within the movement. My aims were to contribute both to the movement and to the FLASG initiative, as well as to earn a degree.

\subsection{Literature and method}

While there is a considerable amount of literature on social movements, there is a relative scarcity of literature relating to 'learning in social movements'. Hall and Turay's (2006) work, which provides a comprehensive overview of the literature in English in the field of social movement learning, suggests that most of the literature in this area focuses on learning that movement members gain from engagement in the external struggles of the movement. There is little documentation of the internal process of movement members learning from each other. Foley's (1999) work however, provided useful concepts for understanding learning within movements and an analytical framework which I adapted for my study. I also drew on relevant insights from development practice, in particular the work of the Community Development Resource Association (CDRA 2007; Kaplan 2002; Reeler 2001, 2005). I was fortunate to be following the path of a fellow movement member, Ingrid Huygens (2007), who had recently completed a doctoral thesis in which she engaged the movement in research. Her work provided a base for my method. 
An interpretative framework of social constructivism and critical theory guided my work. My approach was informed by participatory action research. I conducted three semi-structured interviews, with small groups of two to three people, from each of the first three generations of the Päkehä Treaty workers' movement active in the Auckland region. This was followed by a combined workshop in which participants of all three generations were present. The interviews focused on individuals' learning and the sharing of that learning within the movement. While my questions were applicable to various aspects of Päkehä Treaty work, including approaches to campaigning or education, my focus was on our learning regarding working with Mäori activists in the Tino Rangatiratanga movement.

This article will reflect on that research and explore if and how that learning contributed to the overall capacity development of the movement.

\section{Unintentional capacity development in the movement}

\subsection{Learning as individuals}

I initially considered the influences on learning for individual members of the movement.

Prompts for potential influences were based on categories from Foley's (1999) framework, which 'is intended to contextualise learning and to help understand the complexity of learning in struggle' by considering the micro-politics, ideological and discursive struggles and macropolitics impacting on learning in social action. This brought to the surface the range of influences on movement members' learning and the relative significance of, and relationships between, these influences. ${ }^{4}$ The complex nonlinear nature of learning was highlighted as a number of participants discussed the important learning that came from observing or experiencing behaviour that they did not want to replicate; 'learning what not to do'. One participant also talked about the need to 'unlearn' his own ideas in order to engage in the work.

I had been from a very patronising, colonial, Päkehä point of view of the situation, 'What can I do to help poor downtrodden people?' rather than how could I influence Päkehä... So I came into the movement with a steep learning curve to get to where I am now. (Richard pers. comm.)
Figure 1 Action reflection model demonstrating progression

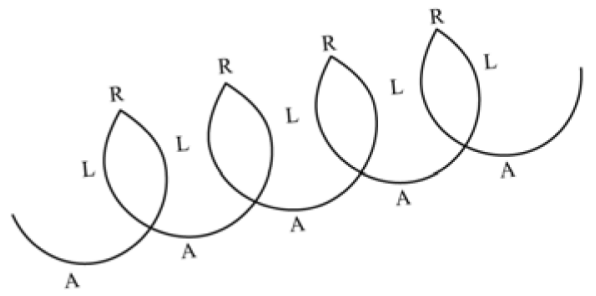

$A=$ acting; $L=$ =earning; $R=$ reflecting

There was a complex interweaving of the different influences in which certain influences might support or contradict others. Individuals were engaged in constant processes of negotiating, reconciling and/or aligning these influences.

Learning was primarily informal and experiential, happened in a range of ways from direct instruction to listening and osmosis, and occurred primarily in the context of action and reflection.

I think of conversations... about power and relationships being held by people rather than the group and they weren't conversations for learning's sake but there was learning in them. (Abigael pers. comm.)

I think just being there when people are thinking out loud and talking through a problem, you can't help learning a lot. (Mitzi pers. comm.)

Participants explained their learning through stories of their experiences in which learning and action were intertwined. They had a sense of constantly learning; however, articulating learning was difficult because of its informal, contextual, organic, non-sequential nature.

The process of learning has been so organic as opposed to formal, that I find this all quite difficult to put it into words. It's not even as simple as one thing led to another.

(Mitzi pers. comm.)

Dickie (1999) has commented that because of the informal nature of learning in social movements, it may not be integrated into ongoing action. While this might be true of collective movement learning, for individuals in 


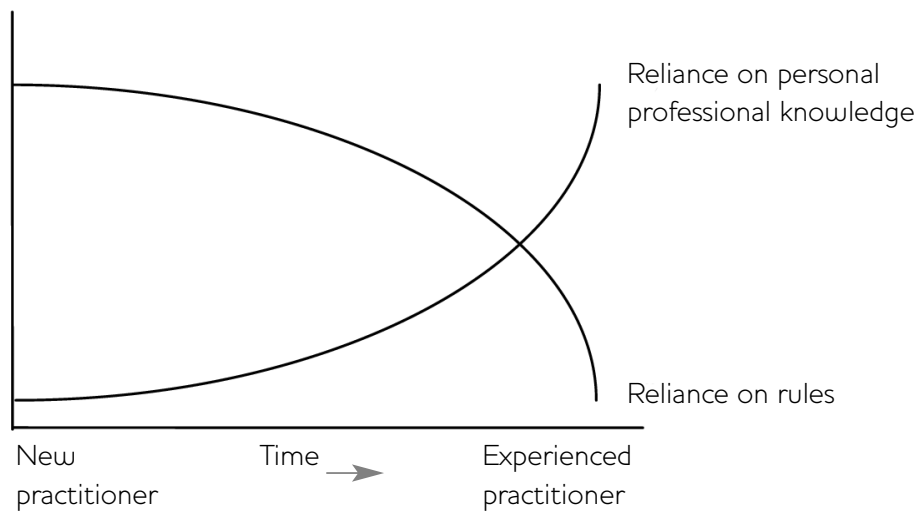

Source Treaty Resource Centre (2008: 2).

this study integrating learning into practice was an ongoing process best described by the Freirean (Freire 1970) notion of praxis.

They experienced a development in their ideas and related actions over time and described this as a growing confidence in their own practice. Figure 1 depicts this.

Participants felt that they had shifted over time from a reliance on existing ideas of practice to their own understandings.

I relied most on my existing ideas about practice from political work in the States. I wouldn't say it's less influential now; I've just woven it into my practice so don't think about it as often. I'm interested in a model that suggests when you start something new you have to rely on the rules as you've got nothing else to rely on. Over time, as you get more experience, you rely less and less on the rules and have more confidence in your own judgements about things and eventually you forget the rules and feel confident what you're doing is right. It can be called intuition, I call it unarticulated knowledge. (Christine pers. comm.)

Figure 2 reflects the model suggested by Christine.

The articulation in Figure 2 usefully reflects the process of individual learning for members of this social movement.

\subsection{Learning as a movement}

Moving from consideration of individual experiences to the collective experiences of the movement highlighted a disjuncture. While individual members were engaged in an ongoing personal learning, at the movement level the sharing of learning in relation to the practice of working with Mäori activists was very limited. Exploration of this provided useful insights into factors impacting on capacity development processes in the movement including: the focus of social movements, movement dynamics, selfperceptions and intergenerational relationships, the imposition of a 'right' way, the relationship between the individual, the movement and broader society and the nature of the practice.

\section{The focus of social movements}

In general, social movements are focused on creating social change external to their movement. Comparatively little attention is paid to internal processes and action is valued over reflection; so, the potential value of movement learning and capacity development may not be recognised or attended to. ${ }^{5}$ Factors which have been identified as impacting on learning in development organisations are also pertinent to social movements: '...aspects of organisational culture that predominate and affect learning include an activist tradition which relegates learning to a secondary role (albeit often unconsciously); heavy workloads and assumed priorities; perceptions of learning as an unnecessary luxury' (Vincent and Byrne 2006: 394). 


\section{Movement dynamics}

Foley discusses the painful learning that can happen during struggles within movements and states that, 'Such struggles have the potential to be destructive and debilitating. But they can also lead to decisive, liberating action, which itself is full of learning for the people involved' (Foley 2001: 77-8). My study showed that there was powerful learning for individuals involved in the struggles within the movement. However, overall, these struggles were more debilitating than enabling in terms of enhancing learning as a movement.

The quality of internal relationships had a major impact on movement members' willingness to share and learn together. There was discussion in all the interviews of how conflict inhibited participation. It was apparent that although the movement has an external focus on social justice, movement members do not always act justly towards each other. Participants reflected that Treaty work entails challenging broader Päkehä society and that this challenging attitude is often carried into interaction between movement members. Because this attitude is only rarely balanced with affirmation, the movement is regarded as not being a safe learning environment.

\section{Self-perceptions and intergenerational relationships}

People's confidence and their perceptions of competence in their own practice also affected their willingness to share learning with others in the movement. Many participants talked about their lack of confidence in relation to practice, experiencing fear, and not knowing what to do. Although participants experienced a growing confidence over time, this was a relative concept; uncertainty about competence was an enduring aspect of many participants' experience.

Participants spoke of being in awe of other people in the movement. Some also described how this inhibited them sharing their learning. Generally, this manifested in non-participation in forums that required sharing or refraining from challenging ideas that they did not agree with.

While discussed by all participants, this was particularly evident for the newest members to the movement. The 'Generation Three' participants in this study had all been in the movement for eight years; yet they still referred to themselves as newcomers or 'newbees' in relation to their elders. ${ }^{6}$
As far as sharing learning I don't think I felt like I had anything to offer with others in the movement because I still consider myself to be a newbee. (Richard pers. comm.)

While Generation Three participants recognised the potential limitations of this awareness of being newcomers, they also had a nuanced understanding of the interaction between the generations and were conscious of the contributions of each generation to the sharing of learning.

I've done lots of learning but have I shared it? In the movement we're in, surely the people who are teachers are learning all the time, so by participating in learning processes hopefully the people who are facilitating your learning are also learning from you. People of our generation enrich and change those conversations by our presence. (Abigael pers. comm.)

This quote highlights the ambiguity and complexity of generational positioning, as Generation Three members hold these views concurrently with the perspective of themselves as 'newbees'. This ambiguity may reflect the interplay of awareness of generational positioning with other aspects of movement dynamics. This study suggested that addressing other aspects which inhibit learning in the movement, for example being in awe of others and feeling inadequate in one's own practice, or the notion that there is one 'right' approach to the work, might diminish inhibitions attributed to generational positioning.

\section{One 'right' way}

Significantly, a central source of conflict in the movement emerged in response to intentional attempts to facilitate capacity development. In the early days of the movement, broader Päkehä society was hostile to the Treaty and by association to the work of Päkehä Treaty workers. Some members of the movement responded with an explicit ideology that they expected all movement members to follow:

There was a strong apprenticeship model and what we'd today call conventional professional development training... it was teaching but it wasn't learning. It was knowledge

transmission. 'This is how we do it'. What was 
missing for me was any opportunity to say 'I don't think this works'. It was discouraged to question. (Christine pers. comm.)

The ways in which this dominant ideology about Päkehä Treaty work was conveyed and enforced not only inhibited learning but led many people to temporarily, and sometimes permanently, distance themselves from the movement. As broader Päkehä society has become more accepting of Päkehä Treaty workers, there has been a greater openness within the movement to a diversity of approaches to the work. People are more open to sharing their learning within the movement and relationships within the movement have strengthened.

Being open to a diversity of approaches may be crucial but it also presents challenges. It raises issues such as how we respond if we think that a member's practice is detrimental to Mäori or the movement. It requires us to consider how we constructively critique and challenge each other's practice and to reflect on the relationship between the individual and the group. As Taylor, Deak, Pettit and Vogel (2006) describe:

There will always be a certain tension between striving toward an articulation of shared values (or group identity) - essential for an organisation to be effective - and the need to have a culture of respect for different values (individual identities). There is a need for some overlap, convergence and alignment, as well as for diversity. Organisations need to reflect on the optimal level of group identity vs. individual identities; diversity and homogeneity (Taylor et al. 2006: 32).

Recognising and attending to this tension is a critical aspect of facilitating capacity development in social movements.

\subsection{The relationship between the individual, the movement and broader society}

In this research, participants were highly aware of how movement dynamics and self-perceptions impacted on engagement in learning within the movement. The research questions also caused people to consider the ways in which broader societal forces form a context that either provides or inhibits opportunities for learning at the micro-political level. Factors such as gender and ethnic relations, the effects of neoliberal reforms on activism, and society's attitudes to the Treaty, were identified as impacting on interaction and learning within the movement. This facilitated an awareness that we could work to build a more affirming and supportive environment in the movement and still find that learning is inhibited in many ways. This finding supports the recognition that in addition to 'the systematic integration of the levels of the individual, organisational and wider society... a nuanced understanding of the specific context... recognising the importance of political, social, economic and cultural factors' (Taylor and Clarke 2008: 3), is a key component of facilitating capacity development.

\subsection{The nature of the practice}

Although overall, the sharing of learning within the movement was limited compared with individual learning, processes of capacity development had been facilitated. National gatherings, monthly meetings of local groups and the action undertaken between these meetings were identified as important spaces for this. Newcomers to the movement have been mentored into the work by more experienced movement members. In these contexts, people learned through conversations, observing other movement members' practice and listening to their experiences.

Joan has done a lot of the transmission into the third generation... [she] has never set out to teach it, she goes into places and makes alliances and it's part of working out 'how are we going to deal with this'? (Mitzi pers. comm.)

The research showed, however, that the learning that was shared was primarily about the practice of Treaty education. There has been very little sharing as a movement about the practice of working with Mäori activists. In considering why this was the case, participants reflected that Treaty education is a fairly well-defined and technical practice which is developed largely within the context of the movement. In contrast, the practice of working with Mäori activists involves working in diverse relationships external to the movement. These relationships are dynamic; so the practice being learned is not fixed.

...I'm working alongside Mäori in a shared way. Knowing how to do that is an ongoing 
learning curve, everyone is different, different Mäori react in different ways to different things. (Richard pers. comm.)

As it is dynamic, relational and contextual, the practice is difficult to share. There is not one common practice or a collective approach. This complexity is characteristic of all relationshipbased work and has clear implications for how we approach capacity development.

Due to the nature of this aspect of practice, participants questioned the appropriateness and value of sharing the specifics as they felt their knowledge may not be relevant to others in different contexts.

I'm hesitant to tell others this is how to do it because they know what their circumstances actually are better than me. Mäori are changing all the time and Päkehä are too; so the next generation has different starting points for their relationships. (Mitzi pers. comm.)

These challenges raise the question of whether it is in fact possible to intentionally facilitate capacity development in regard to relationshipbased practice. The CDRA provides insight into the nature of facilitating capacity development in this context. The CDRA describes development practitioners as working in 'a world of systems, of relationships, of connections; ambiguous, shifting and changing, developing, interweaving, continually being formed and continually changing into something else. In a word dynamic' (CDRA 2007: 86). They suggest that 'A reading of development must remain supple, subtle and nuanced; it must be iterative and gradual; it must be reflective and reflexive' (CDRA 2007: 73).

The Treaty Resource Gentre uses the metaphor of a journey to conceptualise practice based on relationships. 'The emphasis is on travelling together rather than reaching a pre-set destination... The course of the journey is to be mapped through dialogue and negotiation between the parties in the relationship' (The Treaty Resource Centre 2007: 6). This metaphor along with CDRA's work suggests that facilitating capacity development in an area of relationship-based practice requires an awareness of, and attention to, the potential of many different routes which might be taken and the continually emerging nature of the process.
Within the FLASC initiative, I learned a great deal which was relevant to my practice from hearing stories from very different social change contexts. In sharing about practice in diverse relationships and contexts, it may be useful to be explicit that the aim is not to generate a collective practice but to strengthen the practice of the collective through learning from one another. This encourages openness to listening for the similarities and differences in experiences which can enrich understanding of one's own and others' practice.

\section{Intentional facilitation of capacity development}

Other than ad hoc mentoring for some individuals, capacity development through learning within the Päkehä Treaty movement was largely unintentional; however, two intentional processes could be identified: the informal process of intergenerational questioning and the structured process of action research.

\subsection{Intergenerational questioning}

Members of Generation Three of the Päkehä Treaty workers' movement have posed many 'capacity development' questions to the previous two generations such as 'How should we do this?' 'Can we do better?' 'What's been learned that can inform our approach?'. Members of Generations One and Two have commented that these types of questions had not been asked previously, so why did Generation Three ask these questions? Several reasons relate to the life cycle of the movement. The movement had been active for nearly 20 years when Generation Three joined. This was a significant enough time period to allow for reflection on the progress and achievements of the movement. For Generation Three, there was both respect for those who had been doing the work before us and concerns about the efficacy of the movement. Because of our age many of us had not witnessed the positive social changes which had been achieved and were more acutely aware of the enduring and entrenched injustices still to be addressed. Those who had been engaged in the work for many years were aware of the long timeframe for change, in contrast the newer generation was impatient for change. For Generation Three the starting point for the work was to take stock of the work undertaken over the previous 20 years and to consider the efficacy and appropriateness of the approaches taken to the social and political context we inherited. 
These questions may well have been asked but not engaged with by the previous generations. The capacity development process happened because members of Generation One and Two took these questions seriously and made time to respond. What prompted this engagement? Members of Generation Three largely came to the movement as part of a national group of young people with an interest in Treaty justice rather than as individuals. The group was explicit about the role of elders and keen to understand the context of the work. Members of the group used a common language and had consistent questions. Generations One and Two may not have engaged with these questions to the same extent if they had been ad hoc questions from individuals. The painful learning Generation One and Two members had experienced, with regard to accepting a diversity of approaches to the work, had led to a greater openness to questioning of methods. For previous generations, there was also the awareness of the need to attract new people to join and take up the work to ensure the survival of the movement.

This study shows that through their enquiries, newcomers to a social movement can be instigators of capacity development processes. For this to occur, newcomers must feel able to question approaches to practice. Existing movement members need to be open to hearing and responding to these questions and have the time and space to do so. The exchange needs to be understood by both 'new' and 'old' members as a mutual learning process.

\subsection{Action research}

In the Päkehä Treaty workers' movement there are limited resources, especially time, to engage in structured reflective learning processes.

Members undertaking action research within the movement have therefore made a significant contribution to facilitating capacity development.

\section{A proven method}

The methodology and method adopted for my research were strongly influenced by the work of Huygens (2007), who had recently undertaken research as a committed participant within the Päkehä Treaty workers' movement. Huygens' work attested to the support within the movement for action research by members. My building on her work was seen as beneficial:
It feels like it's developing a process, it might not be the only one, but it is a process that has integrity, effectiveness, two way contribution, which is nice to have so that people in our movement feel like 'Research, yay'.

(Christine pers. comm.)

Huygens used Elias's (1994) concept of 'praxis explicator' to describe her practice. As a praxis explicator:

The researcher 'gives back' to practitioners their own best work, in the interests of forging a continuous link from theory to action. The intention is to develop theoretical principles derived from extensively capturing excellent, context-sensitive practice and linking it to theory. In this manner, Elias (1994) considers that a researcher working from the praxis explicator position is able 'to create maps of patterns of change, markers for shifts in terrain, realistic guideposts' for merging theory, research and practice in particular contexts of inquiry. (Huygens 2007: 102)

Huygens explains that this positioning led her to consider herself as a 'co-theoriser alongside the research participants in our mutual quest for understanding' (Huygens 2007: 103) and that this generated reciprocity in the research relationships.

Bevington and Dixon (2005) in their discussion of the need for research relevant to social movements make the point, 'that some of the most helpful research challenges the assumptions upon which movements are developing strategies' (Bevington and Dixon 2005: 199). I was mindful that both the dynamics of the research process and the information that surfaced in the process might be unsettling to participants and to me. Positioning myself as a co-theoriser meant that I was one voice among many in the process; however, as the instigator of the research process, I also held particular responsibilities. I established support networks of movement members and other colleagues to provide guidance to me in the research. These were an important means of structuring the research as a shared endeavour and played a valuable role in generating appropriate responses to these tensions.

\section{An academic project}

Without the motivation of achieving the personal goal of attaining a degree, I would not have made 
the time commitment to this research. The requirements of the academic project meant engaging with literature and undertaking analysis at a new and different level; however, doing the research within an academic context also created constraints. I had to negotiate the differing ethical expectations of the Päkehä Treaty workers' movement and those of the university, specifically with regard to keeping records and anonymity of participants. In the academic context, there was also the concern about my positionality as an 'insider' researcher and the risks associated with this of being 'blinded by the familiar' (Bolak, as cited in Huygens 2007: 96) and challenged by testing 'taken-for-granted views' of my community (Smith 1999: 139). These concerns were balanced by benefits to insider positioning in researching social movements. As Foley comments 'activists are generally most willing to cooperate with researchers who share their broad political goals and who can help them to understand their situations more clearly and act on them more effectively' (Foley 1999: 140-1). Participants remarked on the trust they had in me as a movement member to undertake this work. My existing knowledge of the movement provided me with a greater awareness of the complexity within the movement than an 'outsider' researcher would have (Huygens 2007).

\section{Outcomes for the movement}

From the movement perspective, the research process offered a relatively rare opportunity for a structured reflective space amidst our ongoing action. In the workshop, participants collectively reflected on the research findings and considered the implications for future practice. Practical ideas for action were generated, particularly around promoting greater sharing of learning within the movement through embracing a diversity of approaches to the work and consideration of ways to support newcomers to the movement. Identifying broader societal influences which impact on movement relationships and learning provided for a deeper and more nuanced understanding of practice. It highlighted reasons for the lack of sharing of learning within the movement and made us aware of which of these were internal or external to our influence.

Participants also considered the value of the research process.
It's taking time out to reflect. It's reinforcing that model of action reflection and because of hearing the stories of a group of us who've been involved for different periods of time, it's deepening our knowledge of each other and therefore by implication, that's deepening the movement. (David pers. comm.)

According to Reeler (2005), 'In peer settings, stories and their telling of the past, present and future, can become powerful processes for community consciousness and transformation' (Reeler 2005: 9). The process of each generation reflecting on its story and these being collectively discussed by the research participants at the workshop facilitated greater understanding and insight into movement relationships. The focus on the effectiveness of the movement's work and the implications for future practice was critical to this research being seen by participants as useful and relevant.

\section{Beyond the research project}

As a movement member, I was clear that my commitment went beyond the academic project. This has involved making research records publicly available as agreed by participants and sharing the research findings more widely at a recent national Treaty conference. Writing this article six months after completing the research raises questions for me as to whether this learning has or will translate into capacity development, what my role is in supporting this, and the extent to which this is a shared endeavour. Being part of the movement means I can raise these questions for discussion by research participants and other movement members at our regular local Treaty workers' meeting and thus continue the learning.

Formal action research projects require significant commitment from both the researcher and participants and can be restrictive in their scope and timeframes. For many social movements this form of capacity development process may not be feasible or a priority. Given this, it is important to create less intensive opportunities for capacity development. Regularly responding to a series of questions such as - What have I/we learned in the last month/six months/year? Has this learning led to changes in my/our practice? If not, why not? If so, how has my/our practice changed? - in movement gatherings may help cultivate praxis for individuals and the collective. 


\section{Conclusion: facilitating capacity development within a social movement}

Considering learning within the Päkehä Treaty workers' movement indicates that capacity development processes are happening to different degrees at individual and movement level and in relation to different practices of the movement. For individuals, learning is happening all the time. It is embedded, informal and unarticulated. Capacity development is an unintentional process best described as praxis. At the movement level, capacity development processes are less evident and are affected by an interplay of micro- and macro-factors. While some sharing of learning occurs in relation to defined 'technical' practices of the movement, there is very little in regard to relationship-based practice. Action research is valued as an intentional process that facilitates collective reflection and analysis and generates a deeper understanding of learning within the movement, which might inform future capacity development efforts. The research also suggested that intergenerational dialogue can be an important

\section{Notes}

1 Generation One participants were involved in anti-racism work that preceded Treaty work and had been involved in the Päkehä Treaty workers' movement since its inception in the early 1980s. Generation Two participants joined the movement from the mid-1980s to the mid-1990s and Generation Three participants joined in the period from the late 1990 s to the early 2000 s.

2 Groups of related families; recognised by the British as sovereign bodies before the signing of the Treaty.

3 Traditionally meaning 'ordinary' or 'normal'; used by Europeans to refer to the people

\section{References}

Bevington, D. and Dixon, C. (2005) 'Movementrelevant Theory: Rethinking Social Movement Scholarship and Activism', Social Movement Studies 4.3: 185-208

CDRA (2007) Dreaming Reality: The Future in Retrospect, Cape Town: Community Development Resource Association

Dickie, J. (1999) 'Neighbourhood as Classroom: Reflections of an Activist', in J. Crowther, I. Martin and M. Shaw (eds), Popular Education means of facilitating capacity development within a social movement.

I came into this project with quite a sense about how are we going to be more effective about sharing the knowledge, passing it on, bringing new people in, all that kind of stuff, in my very analytical 'we'll answer this question and then we'll do it' way. The surprise for me was it doesn't feel like that will be doable... it seems like a lot of the learning we do is incidental and contextual. (Christine pers. comm.)

This quote encapsulates how the complexity of facilitating capacity development, particularly with regard to relationship-based practice, became evident in this research. In this context, capacity development is a complex, subtle and ongoing process. While it can be difficult to observe or quantify capacity development outcomes, this article demonstrates the potential value of identifying and seeking to understand both intentional and unintentional capacity development processes in a social movement.

living in Aotearoa when Europeans arrived.

4 Influences included learning from Mäori in a range of contexts, other Päkehä both within and outside the movement, and existing practice.

5 This characteristic is particularly evident within an informal loosely structured movement such as the Päkehä Treaty workers' movement; it may be that larger, more structured social movements are better able to attend to internal processes.

6 While this notion was articulated by all three participants from this generation, it was expressed more strongly by the two younger members.

and Social Movements in Scotland Today, Leicester: National Institute of Adult and Continuing Education (England and Wales): 263-72

Elias, M. (1994) 'Capturing Excellence in Applied Settings: A Participant Conceptualiser and Praxis Explicator Role for Community Psychologists', American Journal of Community Psychology 22.3: 293-318

Foley, G. (2001) 'Radical Adult Education and Learning', International Journal of Lifelong Education 20.1/2: 71-88 
Foley, G. (1999) Learning in Social Action: A Contribution to Understanding Informal Education, London: Zed Books

Freire, P. (1970) Pedagogy of the Oppressed (M. Ramos, trans.), New York: Herder \& Herder

Hall, B. and Turay, T. (2006) State of the Field Report: Social Movement Learning, Vancouver: Canadian Council on Learning

Huygens, I. (2007) 'Processes of Pakeha Change in Response to the Treaty of Waitangi', unpublished PhD, University of Waikato, Hamilton, http://waikato.researchgateway. ac.nz/handle/10289/2589 (accessed 10 February 2009)

Kaplan, A. (2002) Development Practitioners and Social Process: Artists of the Invisible, London: Pluto Press

Margaret, J. (2009) 'Learning in Social Movements: Experiences in the Päkehä Treaty Workers' Movement', unpublished MA, University of Auckland, Auckland, www.awea.org.nz/resources (accessed 18 December 2009)

Reeler, D. (2005) Horizontal Learning: Engaging Freedom's Possibilities 2004/2005 CDRA Annual
Report, www.cdra.org.za/LibraryandResources/ Articles\%20by\%20CDRA.htm (accessed 9 July 2008)

Reeler, D. (2001) Unlearning: Facing Up to the Real Challenge of Learning, www.cdra.org.za/LibraryandResources/Articles \%20by\%20CDRA.htm (accessed 9 July 2008)

Smith, L.T. (1999) Decolonizing Methodologies: Research and Indigenous Peoples, Dunedin: University of Otago Press

Taylor, P. and Clarke, P. (2008) Capacity for a Change, Brighton: IDS

Taylor, P.; Deak, A.; Pettit, J. and Vogel, I. (eds) (2006) Learning for Social Change: Exploring Concepts, Methods and Practice, Brighton: IDS

Treaty Resource Centre (2008) Praxis, www.awea.org.nz/tools (accessed 11 August 2009)

Treaty Resource Centre (2007) Treaty Journeys: International Development Agencies Respond to the Treaty of Waitangi, Wellington: Council for International Development

Vincent, R. and Byrne, A. (2006) 'Enhancing Learning in Development Partnerships', Development in Practice 16.5: 385-99 